\title{
Namnožitev molja macesnovih iglic (Coleophora laricella) v KE Litija
}

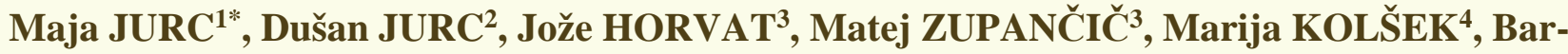 \\ bara SLABANJA ${ }^{5}$
}

Poškodbe iglic je povzročil molj macesnovih iglic (Coleophora laricella (Hübner, 1817)), iz družine vrečonosih vešč (Lepidoptera: Coleophoridae).

Areal molja macesnovih iglic so Alpe, kjer spremlja območje avtohtonega navadnega macesna (Larix decidua Müller) v subalpinskem pasu na karbonatih, zlasti v združbi z rušjem. Pri nas se pojavlja od nižin do nadmorske višine $1500 \mathrm{~m}$. Z macesnom so molja macesnovih iglic zanesli v Azijo in Severno Ameriko. Na Japonskem živi na Larix leptolepis, v Sibiriji na Larix sibirica Ledeb., v Severni Ameriki na Larix occidentalis Nutt. in Larix laricina Koch, redko tudi na Pseudotsuga taxifolia Britt. in Tsuga heterophylla Sarg. V Sloveniji se je molj macesnovih iglic pojavljal v namnožitvah v nasadih na Dolenjskem in v Beli krajini (Vahta, Mirna gora, Sredgora, Planina, Gorjanci, Brezova reber, Smrečnik, Škrilj, Koritniška gmajna, Štehanja vas idr.). Občasno se je namnožil v kulturah in naravnem gozdu tudi drugod (Ljubljana, Mislinja, Glažuta, Nazarje, Ptuj, Slovenske Gorice, Haloze, Bled, Maribor, Sevnica, Brkini, Bovec, Ravne in Črna na Koroškem, Bukovje pri Postojni, Bohor, Luče, Bele vode, Plešivec, Peca, Preddvor pri Kranju, Vransko, Blegoš, Gaberk in Pregarje na Krasu, Kokra in drugod). Leta 1969 se je namnožil na 210 ha, leta 1970 na 639 ha in leta 1971 na 494 ha. Leta 1982 so ga zabeležili na Bregu.

Metulj meri okoli $10 \mathrm{~mm}$ čez razpon kril, je sivorjave barve, sprednja krila so širša kot zadnja, ta so suličasta, temno siva in obkrožena z resicami (slika 2, slika 3). Jajčeca so $0,3 \mathrm{~mm}$ velika, rumenkasta. Odrasla gosenica je dolga okrog $5 \mathrm{~mm}$, rjave barve s temnejšim rjavim vratnim ščitom. Ličinka celotno življenje preživi v tulcu, ki ga gradi iz ene ali več izvotlenih iglic (slika 3). Buba je črno rjava in je v tulcu. Ima enoletno generacijo. Metulji rojijo maja-junija, aktivni so čez dan. Samice odlagajo jajčeca posamično na spodnjo stran iglic na kratkih poganjkih. Po približno 14. dneh se izležejo gosenice, ki prodrejo v iglice in jih votlijo proti vrhu. Pojavijo se prvi vidni znaki poškodb, to so izvotlene iglice, ki so svetlejše barve $\mathrm{v}$ primerjavi $\mathrm{z}$ zdravimi iglicami. V začetku septembra opazimo $\mathrm{v}$ iglicah bele votle predele, ki so dolgi 4-7 mm. Sredi septembra gosenica naredi v osnovi izžrte iglice krožno zarezo in izvotleni del iglice uporabi kot "hiško"mešiček. Mešiček stalno prenaša na sebi, premika se z oprsnimi nogami. Z mešičkom odhaja na zdrave iglice, na katere se pritrdi s svilnatimi nitkami, in jih votli. Nastajajo kratke izžrtine, ker ima gosenica vedno na sebi mešiček in zato ne prodre globoko v iglico, na iglici lahko naredi več izžrtin. Del iglice nad izžrtino se posuši. Jeseni se ličinke $L_{2}$ in $L_{3}$ pripravijo na prezimovanje na vejicah, brstih, na skorji med lišaji, na vejah, deblih in zaprejo odprtino mešička s svilnatimi nit- kami. Spomladi se konec aprila in začetek maja gosenica premakne na mlade iglice. Ko izžre eno iglico se seli na naslednjo in tako poškoduje več iglic. Lahko poškoduje tudi moške in ženske cvetove macesna. Prehranjevanje gosenic traja 3-4 tedne. Pred zabubljenjem gosenica pritrdi mešiček na iglico ali vejico, se spremeni v bubo, ki se po 10. dneh razvije v metulja.

Gosenice C. laricella uničujejo iglice vseh vrst macesnov. Jesenske defoliacije niso nevarne, spomladanske pa so lahko zelo nevarne. Takrat ena gosenica uniči do 10 iglic, to je polovico iglic na enem kratkem poganjku. Pri močnejšem napadu se na kratkem poganjku lahko pojavi večje število gosenic (slika 4). To lahko povzroči popolno defoliacijo macesna. C. laricella se pojavlja na gostiteljih vseh starosti - od triletnih sadik do debeljakov. Napadi so lahko močni v čistih ali mešanih sestojih. Defoliacije so močnejše v vrhu krošnje in se počasi širijo navzdol. Gradacije lahko trajajo več let. V literaturi najdemo podatke, da se je po defoliaciji, ki je trajala 4 leta, zmanjšalo višinsko priraščanje macesnov do $17 \%$, debelinsko pa do $50 \%$. Včasih drevo po spomladanski defoliaciji ne more več obnoviti asimilacijske površine in odmre. $\mathrm{V}$ nekaterih državah poročajo o ponavljajočih se gradacijah do nadmorske višine 1000 m, lahko trajajo tudi 12 let. Iz Amerike poročajo, da se je po 5 let trajajoči gradaciji pojavilo 97 \% zmanjšanje letnega priraščanja več napadenih vrst macesna. Višinski prirastek se je zmanjšal za $50 \%$. Napadeno drevje je bilo zelo občutljivo na okužbe s patogenimi glivami, kot so na primer mraznice.

Naravni dejavniki v veliki meri nadzorujejo velikost in razvoj populacije C. laricella. Mortaliteto povzroča hladno, deževno in vetrovno vreme $\mathrm{v}$ času rojenja in ovipozicije, prav tako nenadne spomladanske ohladitve s poznimi mrazi, časovno neskladje med aktiviranjem gosenic in začetkom odganjanja iglic macesna, predčasno rumenenje in jesensko osutje iglic. Parazitski in predatorski kompleks $C$. laricella je bogat: to so številne vrste iz reda muh, iz družine Tachinidae, kožekrilcev iz druž. Braconidae ter Formicidae ter številne ptice iz reda Passeriformes (sinice, ščinkavci, penice in druge), ki pogosto naravno regulirajo abundanco populacije molja macesnovih iglic. O ukrepanju je malo literaturnih podatkov. V tujini dosegajo v mlajših kulturah dobre rezultate s spomladanskim škropljenjem z oljnimi emulzijami. Uporabljajo tudi feromone (Colowit $\left.{ }^{\circledR}\right)$ za kontrolo populacije.

Vsekakor je pri snovanju novih sestojev in obnovi gozdov pomembno vedno upoštevati ekološke zahteve navadnega macesna in ga pospeševati predvsem na optimalnih rastiščih, na vetru izpostavljenih legah in na višjih nadmorskih višinah, ki ustrezajo navadnemu macesnu in drugim vrstam macesna. 


\section{Viri}

Jurc M. 2008. Gozdna zoologija : [univerzitetni učbenik]. 2. natis. Ljubljana: Biotehniška fakulteta, Oddelek za gozdarstvo in obnovljive gozdne vire, 2008. XI: 348 str.

Maček J. 1990. Listni zavrtači gozdnega rastja v Sloveniji II. Zbornik gozdarstva in lesarstva, 35: 3-28.

Titovšek J. 1994. Gradacije škodljivih gozdnih insektov. Zbornik gozdarstva in lesarstva, 43: 31-76.

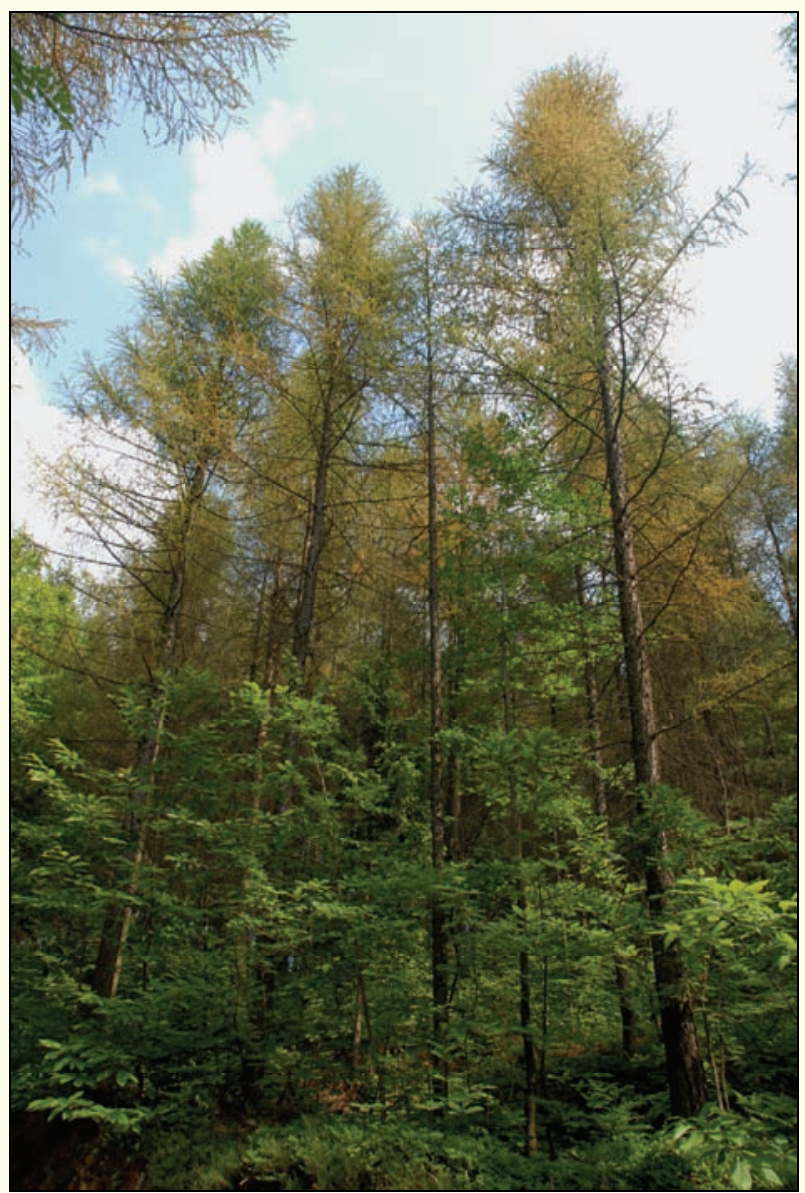

Slika 1: Defoliacijo in rjavenje japonskega macesna v KE Litija je povzročil molj macesnovih iglic (Coleophora laricella), 26. 5. 2011 (foto.: M. Jurc)

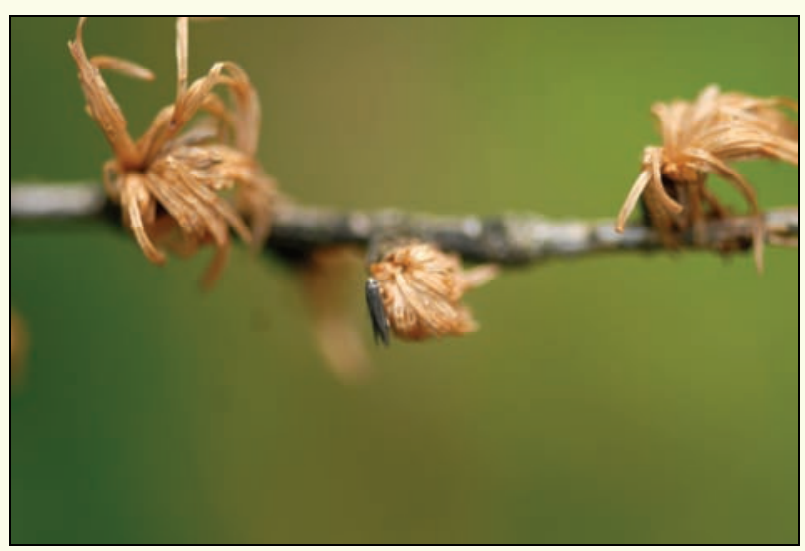

Slika 2: Imago C. laricella (foto.: M. Jurc)
1 Univerza v Ljubljani, Biotehniška fakulteta, Oddelek za gozdarstvo in obnovljive gozdne vire, Večna pot 83, 1000 Ljubljana; ${ }^{2}$ Gozdarski inštitut Slovenije, Oddelek za varstvo gozdov, Večna pot 2, 1000 Ljubljana; ${ }^{3 Z a v o d}$ za gozdove Slovenije, OE Ljubljana; KE Litija, Litijska 20, 1270 Litija; 4 Zavod za gozdove Slovenije, CE, Večna pot 2, 1000 Ljubljana; ${ }^{Z Z a v o d ~ z a ~ g o z d o v e ~ S l o v e-~}$ nije, OE Ljubljana, Tržaška 2, 1000 Ljubljana

*maja.jurc@bf.uni-lj.si

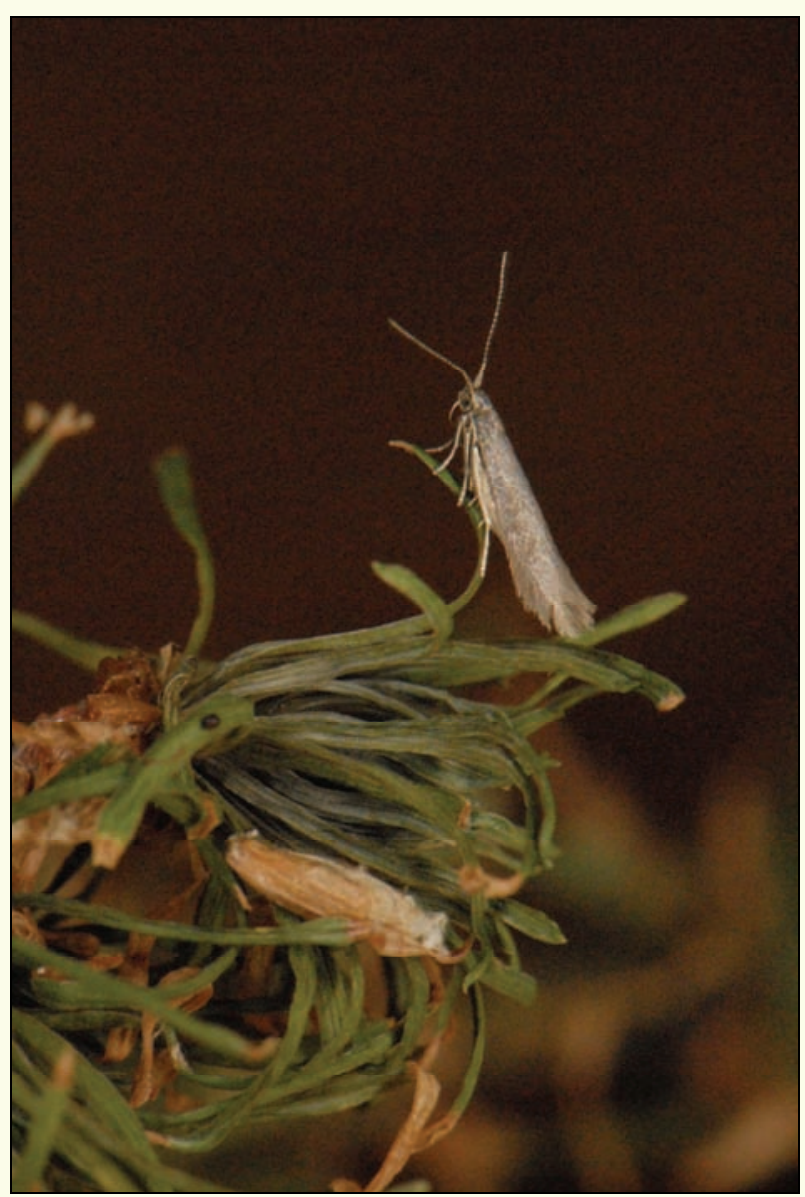

Slika 3: Macesnov molj in mešiček v katerem se je razvil (foto.: D. Jurc)

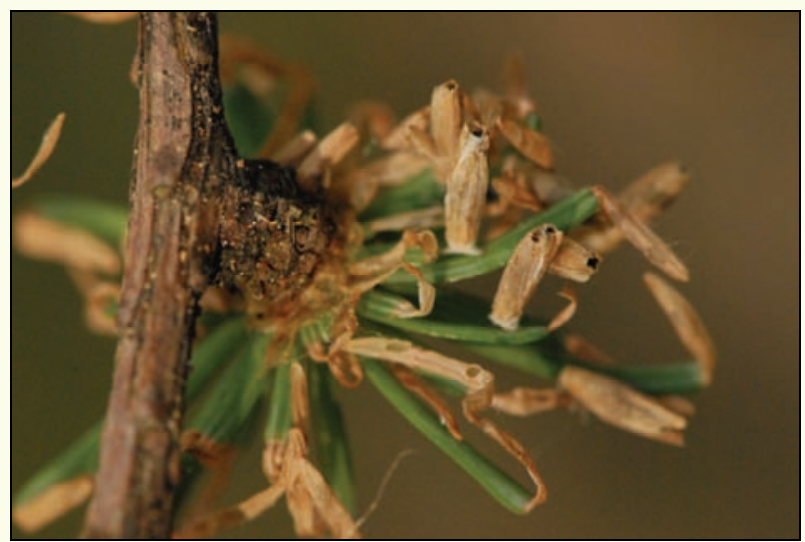

Slika 4: Na enem kratkem poganjku je več mešičkov, ki so dolgi $4 \mathrm{~mm}$ in so odprti z obeh strani, iglice imajo značilne izžrtine (foto.: D. Jurc) 